\title{
Journal of Educational Science and Technology
}

Volume 5 Number 2 August 2019 page 176-188

p-ISSN:2460-1497 and e-ISSN: 2477-3840

DOI: https://doi.org/10.26858/est.v5i2.9687

\section{Information and Communication Technology Approaches and Multimedia Authoring Skills of Public Elementary School Teachers}

\author{
Richard Mendoza Bañez ${ }^{1}$, John Louie Vergara Yedra ${ }^{2}$ \\ ${ }^{1}$ Teacher Education, Batangas State University JPLPC-Malvar, Batangas, Philippines \\ Email: unsunghero25@yahoo.com \\ ${ }^{2}$ Elementary Education, Tanauan City North District, Department of Education, Tanauan City, Philippines \\ Email: yedrajohnlouie23@gmail.com
}

(Received: June-2019; Reviewed: July-2019; Accepted: August-2019; Published: August-2019)

This is an open access article distributed under the Creative Commons Attribution License

CC-BY-NC-4.0 @2019 by author (https://creativecommons.org/licenses/by-nc/4.0/ ).

\begin{abstract}
This descriptive-explanatory research determined the extent of utilization of ICT approaches in performing teaching-related tasks and self-assessment of multimedia authoring skills of 162 public elementary school teachers at Tanauan City North District, Philippines. Utilizing a researcher-made questionnaire in gathering the needed data and applying appropriate statistical tools, the results of the study revealed that the respondents highly utilized technology literacy approach, and utilized both knowledge deepening, and knowledge creation approaches in performing teaching-related tasks as they integrate technology into the curriculum, utilize spreadsheet in monitoring pupils' learning progress, and use available ICT resources to help pupils acquire and demonstrate complex cognitive skills. The respondents were also found to be competent in media literacy, using music and arts, design principles, creativity and novel thinking, and considering audiences as components of multimedia authoring skills that was likely to be influenced by their utilization of ICT approaches as affirmed by the significant relationship identified between the two variables. This study calls for pedagogical innovations by capacitating public elementary school teachers with multi-media authoring skills through ICT-skill enhancement program.
\end{abstract}

Keywords: Educational Innovations, ICT, Multimedia Authoring, Skills, Public Elementary School Teachers.

\section{INTRODUCTION}

Information and Communication Technology (ICT) is radically innovating people's ways of life. As ICT expertise becomes essential in work (Fakhrunnisaa \& Munadi, 2019), study and personal lives, individuals who are tasked to manage the learning systems must prepare people to work with new technologies competently and confidently. Educators are expected to embrace constant changes which can help them transform their pupils into lifelong learners who are engaged in consuming concepts in digital forms which are easily accessed through hyperlinks (Bañez, 2016).

ICT is popularly used in education in designing valuable teaching and learning experiences to increase the interest of pupils and to innovate teachers' instructional practices. However, the educational system in the Philippines faced numerous challenges in integrating technology in the pedagogy to achieve desirable outcomes relative to pupils' performance as demanded by the society; hence, educators are envisioned to recognize the need to equip learners with necessary skills and experience that will enable them to meet the 
standards of 21 st century learners. With this thought, teachers are mandated to develop competency and mastery in the utilization of ICT tools and integration of digital media which can help in developing their knowledge and skills that can revitalize their teaching practices as they respond to the call of producing technologically competitive pupils.

Despite the importance of ICT-related skills in academic workplace, some teachers seem to exhibit minimal or limited skills in ICT utilization and integration which are essential components of the Technological, Pedagogical and Content Knowledge expected from teachers (Mishra \& Koehler, 2006). The widespread utilization of ICT among public schools in the country becomes a challenge for teachers in revolutionizing the quality of education and developing the country. Consequently, UNESCO Institute for Statistics (2014) observed that the integration of ICT into education is frequently resisted by teachers and their unions, particularly in countries with an aging, underpaid teaching workforce and inadequate training and preparation. In these circumstances, lack of motivation to learn new skills in teaching and learning methodologies may occur. This is often compounded by feeling threatened by newer forms of ICT that learners are more capable of comprehending and manipulating compared to their teachers.

The technological revolution which continually shapes the country's educational landscape challenges teachers to develop instructional materials and resources using ICTrelated media in response to the learners' preferences and learning modalities (Ghavifekr \& Rosdy, 2015). Designing the classroom learning experience with consideration to the learners' preference can provide a strong impact to pupils' academic performance (Namaziandost $\&$ Nasri, 2019). Success in teaching depends on a large degree of managing the skills in selecting and organizing content and materials for instruction. Consequently, creating and crafting ICT products where multimedia is the most popular instructional material utilized by teachers involve combining several media that are digitally manipulated such as texts, pictures, graphic arts, sounds, animations and videos that are believed to capture the interest of pupils. The primary purpose of media is to present information in multiple formats through multiple sensory modalities that the pupils can understand and manipulate as the presentation of educational content becomes interactive. This interactive interface produced through multimedia can increase pupils' motivation and engagement in learning contents across subjects. Pupils' exposure to ICT-relative tasks or activities can enhance their skills and capabilities that are essential to digital age such as inventive thinking, higher-order thinking and sound reasoning, effective communication, and high productivity.

Roblyer and Doering (2013) affirmed that UNESCO collaborated with industry partners such as Cisco, Intel, International Society for Technology in Education (ISTE) and Microsoft in identifying Information and Communication Technology (ICT) approaches that can help in specifying the knowledge and competencies expected from teachers who are tasked to bring about the different levels of human capacity development that covers technology literacy, knowledge deepening and knowledge creation. The successful integration of these ICT approaches into the classroom will depend on the ability of teachers to structure the learning environment innovatively to merge new technology into a revitalized pedagogy, to develop socially active classrooms, and to encourage cooperative interaction, collaborative learning and group work that can revolutionize $21^{\text {st }}$ century education (Bañez \& Callo, 2019).

As ICT integration is linked with successful pedagogy, numerous researches attempted to explore teachers' capacity for educational innovations. The report of the Department of Education and Training (2005) on teachers' ICT skills revealed that eight of every 10 teachers rarely used ICT in classroom as their utilization of ICT is restricted to the application of productivity tools such as word processing and spreadsheet. This limited teachers' application of ICT is often associated with minimal access to technical support and computers. Primary and secondary school teachers were found to have lower ICT skill levels compared to their younger counterparts that entails the need for professional development on ICT-based teaching (OECD, 2016; Ramadan, Chen, \& Hudson, 2018). Caluza et al. (2017) encountered similar result indicating the need for teachers to improve their basic knowledge on ICT as it is seen essential to successful computer-aided instruction.

The improvement of ICT skills of teachers is seen possible with ample ICT trainings that can empower and influence them 
to acquire these essential skills that are beyond the basics and enable them to have positive perception on their ICT competencies (Alazam, Bakar, Hamzah, \& Asmiran, 2012). This positive recognition of teachers' ICT skills can motivate them in strengthening their integration of ICT in classroom that can help in transforming them to become efficient ICT users (Aslan \& Zhu, 2018). This transformation on teachers' pedagogic practices infused with multimedia technology integration necessitates the acquisition of multimedia authoring skills. Muraina \& Adeleke (2015) noted that accessibility to multimedia authoring tools had become a prerequisite for ICT classroom integration that can promote teaching effectiveness. Authoring tools with ease of use and learnability properties such as Course Lab and the like can enable teachers to become developers of interactive multimedia that have educational content appropriate for learners and supportive to students' learning modality (Neo \& Neo, 2002; Dağ, Durdu, \& Gerdan, 2013).

Moreover, with the integration of the ICT-related framework to the current educational practice, teachers can help students to create products with the use of multimedia authoring systems which can enhance their skills from basic to extraordinarily complex through collaboration and co-creation. Teachers can help pupils to learn multimedia authoring which comprised of media literacy, using music and art, design principles, creativity and novel thinking and considering audience. Authoring skills in multimedia are utilized in non-trivial task of creating a multimedia production which sometimes called as movies or presentations (Hardman \& Bulterman, 1994). This task involves combining and assembling different media elements, for interactivity and distributing with the end users or the audience learning resources derived from multimedia production (Bulterman \& Hardman, 1995). With this collaboration between teachers and pupils, knowledge and skills in manipulating multimedia software can be enhanced to promote resiliency in the classroom.

With the use of different multimedia systems, the technical skills of people can be developed and enhanced. Multimedia authoring tools play a major role in the school in preparing pupils for the intensive information and visually-oriented world of the future. Learning the tools for multimedia like using presentation software, video production and editing systems and using multimedia/hypermedia authoring software can be a great help for the teachers and pupils to better understand the lesson and explore new possibilities of technology integration beyond classroom. When technologies are properly implemented in the classroom, class discussion can help pupils to be motivated and engaged with real-life situations and collaborative learner-centered environment which will provide opportunities for cooperative thinking and creating (Boholano, 2017). Technologies can also support pupils' learning activities by making their work more efficient and productive which can prepare them to their future works.

As practitioners of educational management and innovation, the researchers believe that the conduct of this study that focused on the extent of utilization of ICT approaches and the assessment multimedia authoring skills of public elementary school teachers is necessary as it can help teachers to strengthen and to elevate their authoring skills in using multimedia in their lessons which can promote classroom innovation. Teachers as the catalyst of change need to accept the challenge of responding to the needs of the 21 st century pupils to help them become lifelong learners. In consonance, the result of this study can help promote the utilization of ICT among teachers to become confident users of multimedia as integrated in their lessons. Designing enhancement ICT program for teachers is essential to help them learn such skills that are important in innovating classroom practices. When teachers are exposed in manipulating ICT tools, they may be able to evaluate and select the most appropriate resources which may be adopted by their pupils.

Objectives of the Study. This study described the ICT approaches and multimedia authoring skills of elementary public school teachers at Tanauan City North District during the school year 2018-2019. This undertaking also identified the significant relationship between extent of utilization of ICT approaches and assessment on multimedia authoring skills that can serve as basis for ICT skills enhancement program for elementary public school teachers.

Specifically, this study aimed to identify the respondents' extent of utilization of ICT approaches with respect to technology literacy, knowledge deepening, knowledge creation; determine the respondents' self-assessment on 
multimedia authoring skills in terms of media literacy, using music and arts, design principles, creativity and novel thinking, and considering audience; and to determine significant relationship between respondents' extent of utilization of ICT approaches and their selfassessment on multimedia authoring skills.

\section{METHOD}

This descriptive explanatory research utilized quantitative data derived from the responses of 162 public elementary school teachers at Tanauan City North District, Philippines. This incidental sample made use of convenient nonprobability sampling covering the total enumeration of teachers handling elementary school graders in the same district. These teachers had provided their consent to participate as respondents of the study.

Research Instrument. A researchermade questionnaire was used as the primary tool for gathering the pertinent data on the respondents' extent of utilization of ICT approaches and their assessment on their multimedia authoring skills. The questionnaire consists of two parts. The first part surveys the respondents' extent of utilization of ICT approaches while the second part determines their self-assessment on multimedia authoring skills. The item statements on the questionnaire are based on the ICT approaches and multimedia authoring skills expected from teachers as $21 \mathrm{st}$ century educators. The extent of utilization of ICT approaches covers the areas on technology literacy, knowledge deepening and knowledge creation. Meanwhile, the assessment on multimedia authoring skills involves areas such as media literacy, using music and arts, design principles, creativity and novel thinking, and considering audience.

The responses in the questionnaire were given in a fixed alternative format. A four-point Likert's scale was used as options for the responses. The verbal interpretations of the options for the extent of utilization of ICT approaches and assessment on multimedia authoring skills are illustrated as follows: 3.504.00 Often/Highly Utilized or Strongly Agree/Highly Competent, 2.50-3.49 Sometimes/Utilized or Agree/Competent, 1.502.49 Seldom/Slightly Utilized or Slightly Agree/Slightly Competent, and 1.00-1.49 Never/Not Utilized or Disagree/Not Competent.

The researchers prepared a draft of the questionnaire and consulted four experts with doctorate degree in educational management, an education program supervisor responsible for the district's educational innovation, and a registered psychometrician for content validation. Suggestions from the mentioned experts were collated and a final copy of the questionnaire was prepared. The questionnaire was also tested for internal consistency. The final copy of the instrument was given to a sample of 31 teachers who were not part of the respondents for reliability testing. Cronbach's alpha coefficient was computed to assess the internal consistency of the item statements along the extent of utilization of ICT approaches and self-assessment on multimedia media authoring skills. With the same computed values of 0.96 that are greater than 0.70 for extent of utilization of ICT approaches and self-assessment on multimedia media authoring skills, the item statements in the questionnaire were affirmed as sufficiently reliable. After establishing the validity and reliability of the questionnaire, the final version was administered to the target respondents.

Data Gathering Procedure. After the preparation of the questionnaire, it was reproduced to gather the needed data. The researchers sought permission from the Division Office of Tanauan City for the conduct of the study. After the approval, letters addressed to the school principals, school heads, or teachersin-charge among the elementary schools at Tanauan City North District were prepared and sent to their respective authorities. Appointments of visits and data gathering were scheduled. The researchers personally administered the questionnaire among the respondents who had provided their consent to participate in the study to clarify its contents and purpose. Retrieval of the questionnaire was also done by the researchers. The obtained data from the responses made by the respondents on the administered questionnaire were tallied, tabulated, analyzed and interpreted using mean, standard deviation, Pearson's r, and T-test.

\section{RESULTS AND DISCUSSION}

\section{Results}

In order to determine the extent of utilization of the Information and Communication Technology (ICT) approaches, the respondents were surveyed on the frequency 
that they perform the ICT approaches in executing their numerous teaching tasks. Options on the frequency of performing each task specified in the questionnaires were provided such as never, seldom, sometimes, and often. These provided options on the frequency of performing the ICT approaches-related tasks have their corresponding numerical values to indicate the opposite extreme of the extent of utilization such as never utilized to highly utilized.

Table 1 shows the respondents' extent of utilization of ICT Approaches in terms of technology literacy. The overall mean of 3.53 suggests that respondents highly utilized technology literacy approach as they often perform teaching-related tasks that required the utilization of such approach like integrating the use of technology into the curriculum for the enhancement of the lesson $(\overline{\mathrm{x}}=3.69)$, conducting classroom activities and presentations using ICT tools $(\overline{\mathrm{x}}=3.69$ ), using presentation software and other digital media for instructional presentations $(\overline{\mathrm{x}}=3.65)$, and other related tasks.

Table 2 presents the respondents' extent of utilization of knowledge deepening approach. The overall mean of 3.45 reveals that the respondents utilized knowledge deepening approach in performing teaching-related tasks as they sometimes perform almost all of the tasks that entail the use of this ICT approach such as examining the appropriateness of variety of software packages in support to pupils' understanding of key concepts and application to solve complex problem $(\overline{\mathrm{x}}=3.35)$, integrating online materials that facilitate pupils' deep understanding of key concepts $(\overline{\mathrm{x}}=3.35)$, and other similar tasks.

Table 3 illustrates the respondents' extent of utilization of knowledge creation approach. This approach characterized by commitment on generating knowledge using ICT tools is found to be utilized by the respondents as revealed by the overall mean of 3.45. The respondents sometimes utilize all the pedagogical tasks relative to this approach which include guiding students in designing project plans and activities that engage them in collaborative problem solving, research or artistic creation which ICT enhances their work $(\bar{x}=3.37)$ and the like.

In assessing the competence of the respondents on their multimedia authoring skills, self-assessment anchored on reflective andragogy was utilized. This self-assessment on multimedia authoring skills involved the honest responses made by the respondents dealing with their capability in designing and developing ICT-supported educational resources as elementary school teachers. Respondents were asked to specify their extent of agreement to each item statement on multimedia authoring skills to reveal their self-assessed level of competence.

Table 4 to 8 encompass the respondents' self-assessment on their multimedia authoring skills. Among these skills essential in designing and developing multimedia, they evaluated themselves highly competent in media literacy. This highly competent evaluation on media literacy skill among the respondents is likely to be the result of their rigorous integration of both multimedia and hypermedia in their classroom discussion $(\bar{x}=3.66,3.60 \& 3.46)$, and their ability to apply ethical, responsible, and appropriate multimedia and hypermedia utilization $(\bar{x}=3.67,3.60 \& 3.69)$. Meanwhile, they assessed themselves as competent in multimedia authoring skills covering the dimensions of using music and arts, design principles, creativity and novel thinking, and considering audience. This competent assessment on multimedia authoring skills seems to indicate the need to strengthen the elementary school teachers' capability in making an audio-video recording $(\overline{\mathrm{x}}=3.27)$ and enhancing it with the aide of video-editing software $(\bar{x}=3.26)$ to further hone their skills in using music and arts, and design principles. Likewise, opportunity for improvement is seen in their ability to create engaging online materials $(\bar{x}=3.26)$, and disseminating results of their researches using presentation software $(\bar{x}=3.18)$ as significant skills in creativity and novel thinking, and considering audience.

The quantitative data generated from the responses of the respondents were treated with Pearson's $r$ and T-test to determine relationship between their extent of utilization of ICT approaches and their self-assessment on multimedia authoring skills. Result of the test of correlation is illustrated in Table 9. The table reveals the relationship between the respondents' extent of utilization of ICT approaches and their assessment on their multimedia authoring skills. It shows that when the respondents' extent of utilization of ICT approaches was correlated with their selfassessment on multimedia authoring skills, the correlation generated the computed t-value of 
16.190 with its corresponding p-value. The computed $\mathrm{p}$ value of 0.000 is found to be less than the 0.05 alpha level; hence, the researchers afforded to reject the null hypothesis and affirmed that there is significant relationship between the respondents' extent of utilization of ICT approaches and their self-assessment on multimedia authoring skills.

Table 1. Extent of Utilization of Technology Literacy Approach

\begin{tabular}{|c|c|c|c|}
\hline Item Statement & $\overline{\mathbf{x}}$ & SD & $\begin{array}{c}\text { Verbal } \\
\text { Interpretation } \\
\end{array}$ \\
\hline \multicolumn{4}{|l|}{$\begin{array}{l}\text { In performing numerous teaching-related tasks as an elementary school } \\
\text { teacher, I... }\end{array}$} \\
\hline $\begin{array}{l}\text { 1. integrate the use of technology into the curriculum for the enhancement of } \\
\text { the lesson. }\end{array}$ & 3.69 & 0.48 & Often \\
\hline 2. conduct classroom activities and presentations using ICT tools. & 3.57 & 0.56 & Often \\
\hline 3. utilize available software packages for a specific subject area. & 3.48 & 0.62 & Sometimes \\
\hline $\begin{array}{l}\text { 4. use basic internet application software such as web browser, internet } \\
\text { explorer etc. }\end{array}$ & 3.43 & 0.60 & Sometimes \\
\hline $\begin{array}{l}\text { 5. use presentation software and other digital media for instructional } \\
\text { presentations (e.g. power point and video presentations). }\end{array}$ & 3.65 & 0.50 & Often \\
\hline $\begin{array}{l}\text { 6. demonstrate basic operation of various types of hardware such as desktop } \\
\text { computer, laptop, printer, scanner and projector. }\end{array}$ & 3.50 & 0.52 & Often \\
\hline 7. search information in the internet and world wide web for the lesson. & 3.56 & 0.53 & Often \\
\hline $\begin{array}{l}\text { 8. use email, messenger, video conferences to communicate and collaborate } \\
\text { with teachers, parents and pupils. }\end{array}$ & 3.51 & 0.61 & Often \\
\hline $\begin{array}{l}\text { 9. design lesson plans that incorporate tutorial, drill and practices software, } \\
\text { and digital resources. }\end{array}$ & 3.56 & 0.59 & Often \\
\hline 10. develop assessment tests that incorporate software applications. & 3.31 & 0.69 & Sometimes \\
\hline Overall & 3.53 & 0.57 & Highly Utilized \\
\hline
\end{tabular}

Table 2. Extent of Utilization of Knowledge Deeping Approach

\begin{tabular}{|c|c|c|c|}
\hline Item Statement & $\overline{\mathbf{x}}$ & SD & $\begin{array}{c}\text { Verbal } \\
\text { Interpretation }\end{array}$ \\
\hline \multicolumn{4}{|l|}{$\begin{array}{l}\text { In performing numerous teaching-related tasks as an elementary school } \\
\text { teacher, I... }\end{array}$} \\
\hline $\begin{array}{l}\text { 1. analyze the advantages of different approaches in responsible use of ICT } \\
\text { tools. }\end{array}$ & 3.52 & 0.52 & Often \\
\hline $\begin{array}{l}\text { 2. examine the appropriateness of variety of software packages in support to } \\
\text { pupils' understanding of key concepts and application to solve complex } \\
\text { problem. }\end{array}$ & 3.35 & 0.51 & Sometimes \\
\hline $\begin{array}{l}\text { 3. use ICT software in measuring students' understanding in a specific } \\
\text { lesson. }\end{array}$ & 3.45 & 0.52 & Sometimes \\
\hline $\begin{array}{l}\text { 4. use technology to support project-based learning for students' } \\
\text { understanding (e.g. making videos and presentations). }\end{array}$ & 3.38 & 0.58 & Sometimes \\
\hline $\begin{array}{l}\text { 5. integrate online materials that facilitate pupils' deep understanding of key } \\
\text { concepts (e.g. video clips, youtube, pdf files). }\end{array}$ & 3.35 & 0.62 & Sometimes \\
\hline $\begin{array}{l}\text { 6. use visualization, data analysis, role-play simulations and online } \\
\text { references in teaching my subject matter. }\end{array}$ & 3.42 & 0.59 & Sometimes \\
\hline $\begin{array}{l}\text { 7. communicate and collaborate with pupils, peers and parents through } \\
\text { different forms of media (like facebook, messenger, email) to enhance } \\
\text { pupils' learning. }\end{array}$ & 3.49 & 0.61 & Sometimes \\
\hline $\begin{array}{l}\text { 8. manage, assess and monitor progress of various student projects through } \\
\text { the use of excel in computing grades }\end{array}$ & 3.56 & 0.52 & Often \\
\hline $\begin{array}{l}\text { 9. use varied resources for collaborative project using search engines (e.g. } \\
\text { Google, Mozilla Firefox, Internet Explorer). }\end{array}$ & 3.57 & 0.54 & Often \\
\hline 10. discuss effects of cyber bullying and responsible use of media. & 3.47 & 0.55 & Sometimes \\
\hline Overall & 3.45 & 0.56 & Utilized \\
\hline
\end{tabular}


Table 3. Extent of Utilization of Knowledge Creation Approach

\begin{tabular}{|c|c|c|c|}
\hline Item Statement & $\overline{\mathbf{x}}$ & SD & $\begin{array}{c}\text { Verbal } \\
\text { Interpretation }\end{array}$ \\
\hline \multicolumn{4}{|l|}{$\begin{array}{l}\text { In performing numerous teaching-related tasks as an elementary school } \\
\text { teacher, I... }\end{array}$} \\
\hline $\begin{array}{l}\text { 1. enhance the needed skills on students' problem solving, communication, } \\
\text { collaboration and critical thinking with the use of different ICT } \\
\text { equipment available in the classroom. }\end{array}$ & 3.49 & 0.50 & Sometimes \\
\hline $\begin{array}{l}\text { 2. incorporate the acquisition and demonstration of one or more complex } \\
\text { cognitive skills in own work with the students with the use of different } \\
\text { ICT equipment available in the classroom. }\end{array}$ & 3.59 & 0.50 & Often \\
\hline $\begin{array}{l}\text { 3. assist students to use ICT in searching, managing, analyzing, evaluating } \\
\text { and using information for their own learning about technology } \\
\text { orientation. }\end{array}$ & 3.46 & 0.55 & Sometimes \\
\hline $\begin{array}{l}\text { 4. develop and use both knowledge and performance-based rubrics to } \\
\text { assess students' understanding of key concepts and ICT skills. }\end{array}$ & 3.44 & 0.63 & Sometimes \\
\hline $\begin{array}{l}\text { 5. guide students in designing project plans and activities that engage them } \\
\text { in collaborative problem solving, research or artistic creation which ICT } \\
\text { enhances their work. }\end{array}$ & 3.37 & 0.58 & Sometimes \\
\hline $\begin{array}{l}\text { 6. design ICT-based knowledge communities to support knowledge } \\
\text { creation skills and reflective learning for students. }\end{array}$ & 3.34 & 0.61 & Sometimes \\
\hline $\begin{array}{l}\text { 7. demonstrate digital production resources to support students' innovation } \\
\text { and knowledge creation practices. }\end{array}$ & 3.44 & 0.68 & Sometimes \\
\hline $\begin{array}{l}\text { 8. encourage and share best practices in teaching to other teachers in using } \\
\text { the ICT resources. }\end{array}$ & 3.48 & 0.56 & Sometimes \\
\hline $\begin{array}{l}\text { 9. concretize a vision of the school as a community based on innovation } \\
\text { and continuous learning enriched by ICT. }\end{array}$ & 3.38 & 0.60 & Sometimes \\
\hline $\begin{array}{l}\text { 10. demonstrate a variety of virtual and knowledge-building environments to } \\
\text { support student learning communities. }\end{array}$ & 3.46 & 0.64 & Sometimes \\
\hline Overall & 3.45 & 0.58 & Utilized \\
\hline
\end{tabular}

Table 4. Assessment on Multimedia Authoring Skills as to Media Literacy

\begin{tabular}{|c|c|c|c|}
\hline Item Statement & $\overline{\mathbf{x}}$ & SD & $\begin{array}{c}\text { Verbal } \\
\text { Interpretation }\end{array}$ \\
\hline $\begin{array}{l}\text { As an elementary grade school teacher, I am capable of... } \\
1 . \quad \text { searching information sources for lesson which are age-appropriate for } \\
\text { the pupils. }\end{array}$ & 3.69 & 0.49 & Strongly Agree \\
\hline $\begin{array}{l}\text { 2. discussing media to pupils from common point of views with ethical } \\
\text { considerations. }\end{array}$ & 3.67 & 0.51 & Strongly Agree \\
\hline $\begin{array}{l}\text { 3. using multimedia/hypermedia for instructional purposes in the } \\
\text { classroom discussion. }\end{array}$ & 3.66 & 0.50 & Strongly Agree \\
\hline $\begin{array}{l}\text { 4. making judgment about the integrity of the source and content of the } \\
\text { information to know the reliable sources. }\end{array}$ & 3.39 & 0.64 & Agree \\
\hline $\begin{array}{l}\text { 5. integrating media in some traditional subjects and other interdisciplinary } \\
\text { studies for the enhancement of the lesson. }\end{array}$ & 3.60 & 0.54 & Strongly Agree \\
\hline 6. engaging in ethical and responsible use of media in whole class setting. & 3.60 & 0.56 & Strongly Agree \\
\hline 7. developing media in variety of forms for teaching-learning process. & 3.46 & 0.55 & Agree \\
\hline Overall & 3.58 & 0.54 & $\begin{array}{c}\text { Highly } \\
\text { Competent }\end{array}$ \\
\hline
\end{tabular}


Table 5. Assessment on Multimedia Authoring Skills as to Using Music and Arts

\begin{tabular}{|c|c|c|c|}
\hline Item Statement & $\overline{\mathbf{x}}$ & SD & $\begin{array}{c}\text { Verbal } \\
\text { Interpretation }\end{array}$ \\
\hline \multicolumn{4}{|l|}{ As an elementary grade school teacher, I am capable of... } \\
\hline $\begin{array}{l}\text { 1. composing music with the use of different software that can create } \\
\text { wonderful melodic compositions as instructional material. }\end{array}$ & 3.22 & 0.72 & Agree \\
\hline 2. adding music in making power point and editing video presentations. & 3.33 & 0.65 & Agree \\
\hline $\begin{array}{l}\text { 3. making sounds as a source of comprehensible input for pupils in } \\
\text { listening additional information in the lesson. }\end{array}$ & 3.43 & 0.60 & Agree \\
\hline $\begin{array}{l}\text { 4. recording performances of pupils through audio-video recorder as } \\
\text { assessment in the lesson and mode of verification. }\end{array}$ & 3.27 & 0.70 & Agree \\
\hline $\begin{array}{l}\text { 5. providing mnemonics and iconic or pictorial aids as instructional } \\
\text { material in classroom discussion. }\end{array}$ & 3.48 & 0.59 & Agree \\
\hline $\begin{array}{l}\text { 6. converting static pictures into high quality animated color graphics with } \\
\text { audio tracks for making presentation. }\end{array}$ & 3.33 & 0.62 & Agree \\
\hline \multirow{2}{*}{$\begin{array}{l}\text { 7. making videos which combine music and artistic presentations as visual } \\
\text { aid. } \\
\text { Overall }\end{array}$} & 3.32 & 0.70 & Agree \\
\hline & 3.34 & 0.65 & Competent \\
\hline
\end{tabular}

Table 6. Assessment on Multimedia Authoring Skills as to Design Principles

\begin{tabular}{|c|c|c|c|}
\hline Item Statement & $\overline{\mathbf{x}}$ & SD & $\begin{array}{c}\text { Verbal } \\
\text { Interpretation }\end{array}$ \\
\hline As an elementary grade school teacher, I am capable of... & & & Strongly Agree \\
\hline 1. adding text in a graphic/picture. & 3.59 & 0.56 & \\
\hline $\begin{array}{l}\text { 2. editing pictures through the use of photo editing softwares like adobe } \\
\text { photoshop and microsoft photo editor. }\end{array}$ & 3.33 & 0.70 & Agree \\
\hline 3. making videos with the use of different softwares. & 3.28 & 0.66 & Agree \\
\hline $\begin{array}{l}\text { 4. presenting text/information in multimedia applications using standard } \\
\text { font style, design, size, background, etc. }\end{array}$ & 3.62 & 0.50 & Strongly Agree \\
\hline 5. combining sound/videos with audacity in single presentation. & 3.42 & 0.60 & Agree \\
\hline Overall & 3.45 & 0.60 & Competent \\
\hline
\end{tabular}

Table 7. Assessment on Multimedia Authoring Skills as to Creativity and Novel Thinking

\begin{tabular}{lccc}
\hline \multicolumn{1}{c}{ Item Statement } & $\overline{\mathbf{x}}$ & SD & $\begin{array}{c}\text { Verbal } \\
\text { Interpretation }\end{array}$ \\
\hline As an elementary grade school teacher, I am capable of... & 3.36 & 0.68 & Agree \\
1. $\begin{array}{l}\text { combining images and animations in one single coherent interface. } \\
\text { 2. identifying relevant data which information can be presented to pupils. }\end{array}$ & 3.35 & 0.59 & Agree \\
3. designing text and graphics that value the interest of pupils. & 3.41 & 0.55 & Agree \\
4. $\begin{array}{l}\text { creating multimedia projects with the software available for young } \\
\text { children. }\end{array}$ & 3.33 & 0.66 & Agree \\
5. $\begin{array}{l}\text { specifying the multimedia object that should be retrieved immediately } \\
\text { for display. }\end{array}$ & 3.38 & 0.63 & Agree \\
6resenting valuable information to pupils in their lesson (text, pictures, \\
$\begin{array}{l}\text { movies, audio, etc.). } \\
\text { managing project-based learning activities in a technology-enhanced } \\
\quad \text { environment. }\end{array}$ & 3.49 & 0.59 & Agree \\
8. $\begin{array}{l}\text { creating online materials and activities that engage pupils in } \\
\text { collaborative problem solving, research or artistic creation. }\end{array}$ & 0.59 & Agree \\
\hline$\quad$ Overall & 3.26 & 0.72 & Agree \\
\hline
\end{tabular}


Table 8. Assessment on Multimedia Authoring Skills as to Considering Audience

\begin{tabular}{|c|c|c|c|}
\hline Item Statement & $\overline{\mathbf{x}}$ & SD & $\begin{array}{c}\text { Verbal } \\
\text { Interpretation }\end{array}$ \\
\hline $\begin{array}{l}\text { As an elementary grade school teacher, I am capable of... } \\
\text { 1. making multimedia presentations that are age-appropriate. }\end{array}$ & 3.57 & 0.53 & Strongly Agree \\
\hline $\begin{array}{l}\text { 2. publishing my research output that can be source of information to other } \\
\text { researchers. }\end{array}$ & 3.28 & 0.72 & Agree \\
\hline $\begin{array}{l}\text { 3. joining research/paper presentation with the aide of presentation tools to } \\
\text { raise audience awareness on a specific problem. }\end{array}$ & 3.18 & 0.74 & Agree \\
\hline $\begin{array}{l}\text { 4. sharing valuable information in my social media accounts that provide } \\
\text { pupils for additional knowledge/ information. }\end{array}$ & 3.48 & 0.57 & Agree \\
\hline $\begin{array}{l}\text { 5. uploading some instructional materials and lesson plans in Facebook or } \\
\text { other social media accounts. }\end{array}$ & 3.43 & 0.58 & Agree \\
\hline $\begin{array}{l}\text { 6. constructing interactive multimedia for pupils' engagement and } \\
\text { learning. }\end{array}$ & 3.31 & 0.65 & Agree \\
\hline $\begin{array}{l}\text { 7. collaborating and communicating with others in using multimedia in } \\
\text { teaching. }\end{array}$ & 3.45 & 0.54 & Agree \\
\hline Overall & 3.39 & 0.62 & Competent \\
\hline
\end{tabular}

Table 9. Relationship between Respondents' Extent of Utilization of ICT Approaches and their Assessment on their Multimedia Authoring Skills

\begin{tabular}{cccccc}
\hline Variables & $\begin{array}{c}\text { Computed } \\
\text { Pearson } \mathbf{r}\end{array}$ & Computed t & p Value & Decision (Ho) & $\begin{array}{c}\text { Verbal } \\
\text { Interpretation }\end{array}$ \\
\hline $\begin{array}{c}\text { Employed ICT } \\
\text { Approaches and } \\
\text { Assessed }\end{array}$ & 0.546 & 16.190 & 0.000 & Reject & Significant \\
$\begin{array}{c}\text { Multimedia } \\
\text { Authoring Skills }\end{array}$ & & & & & \\
\hline
\end{tabular}

\section{Discussion}

This study determined the extent of utilization of the Information and Communication Technology (ICT) approaches in terms of technology literacy, knowledge deepening, and knowledge creation approaches by public elementary school teachers. The results revealed that teachers highly utilized technology literacy approach in performing teaching-related tasks for they were trained in technology utilization as it plays vital roles in teaching pupils. They often integrate the use of technology into the curriculum for the enhancement of their lessons making them literate in using technology in the pedagogy as they utilize ICT tools as instructional materials to scaffold challenging concepts for their pupils to better understand the lesson. Estes (2017) supported this idea as he mentioned that the integration of technology in classroom instruction can enhance pupils' engagement maximizing learning which often leads to a learner-centered pedagogy. This technology integration in learning provides high-quality lessons supported by technology-enriched classroom for the learners. Similarly, Fortich et al. (2014) observed that teachers are excellent in the actual process of ICT operations in the classroom.

Meanwhile, teachers were found to utilize knowledge deepening approach in performing teaching-related tasks. This result suggests that the respondents moderately integrate this approach as they sometimes examine the appropriateness of variety of software packages in support to pupils' understanding of key concepts and application to solve complex problem and integrate online materials that facilitate pupils' deep understanding of key concepts suggesting that they had spent minimal time in examining variety of software packages and selecting online materials to be integrated in classroom to enhance the pupils' understanding of key concepts. This notion is affirmed by Liwanag (2015) by clarifying that teachers are competent in utilizing computer but have limited time of exploring software resources that are available.

The knowledge creation approach was also found to be utilized by the respondents as they sometimes design ICT-based knowledge communities to support knowledge creation skills and reflective learning for pupils. This 
moderate frequency of utilizing this ICT approach to pedagogy connotes that the elementary school teachers seem to be challenged of establishing ICT-based knowledge communities for their pupils as they were used to provide direct scaffold to their pupils. Baytak and Land (2011) observed that teachers were still challenged of promoting an ICT-based classroom with the use of ICT tools and software packages to engage pupils in constructivist oriented learning.

With regards to public elementary school teachers' self-assessment on their multimedia authoring skills, the self-evaluation made on these skills essential in designing and developing multimedia revealed that they were highly competent in media literacy and competent in using music and arts, design principles, creativity and novel thinking, and considering audience. The highly competent media literacy skills of the respondents connotes their fluency in responsible media utilization for teaching by selecting and choosing media sources for teaching with consideration to their pupils' age and interest. Poole and Sky-Mcllvain (2009) stressed that educators have responsibility to filter media and internet resources considering their appropriateness to the pupils' age and the value of information they contain. Likewise, Pond (2013) noted that teachers' acquaintance with responsible media utilization seemed to be the result of rigorous trainings that enhanced their skills on understanding the economics of media industries and awareness of authorship and point of view that enable them to evaluate, construct, and deconstruct media messages.

The elementary school teachers' assessment that they were competent in using music and arts, and design principles dimensions of multimedia authoring skills suggests that they were challenged of recording and editing videos with the use of different software packages. This result implies the need and the importance of acquainting teachers with the latest software tools that can enhance their skills in video editing. Bautista and Bautista (2015) confirmed that teachers are acquainted in utilizing multimedia presentations like animations, web designing, PowerPoint and video presentation through GIF and other modalities in teaching; however, they possess limited skills in video editing due to minimal knowledge of video editing software packages.
Meanwhile, the respondents' assessment that they were competent in creativity and novel thinking as authoring skill in multimedia revealed their minimal capability of creating online materials and activities that engage pupils in collaborative problem solving, research or artistic creation compared with other skills. This result manifests the need for teachers' training in creating online materials such as portable document format and the like to help their pupils in developing their problem solving skills and research skills to be critical thinkers. In the same manner, Eriști et al. (2012) noted that there is a need to train teachers in using up-to-date technologies to benifit their learners. This training may include utilization of ready-made online activities to effectively facilitate discussion.

The respondents were also found competent in considering audience as multimedia authoring skill. This result can be attributed to their moderate capability in joining research or paper presentation with the aide of presentation tools to raise audience awareness on a specific problem which necessitates teachers' increased motivation on this aspect of the pedagogy. As a response to this challenge, the Department of Education (DepEd) in the Philippines had included conducting of research as one of the guidelines for promotion. Based on DepEd Order No. 66, s. 2007, research presentation or publication is essential qualification for teaching personnel promotion to master teachers (Llego, 2019).

The result affirming that the public elementary school teachers' utilization of ICT approaches is significantly related to their selfassessment on multimedia authoring skills capitalizes the notion that the 21 st century teachers effectively integrate technology into teaching which help them develop their multimedia authoring skills as they respond to the nature and needs of the contemporary pupils who are technology-oriented visual learners. Hawkins (2010) emphasized that teachers are effective in utilizing the technology in the classroom for literacy instruction by which the learners demonstrated an increase in motivation, attention and engagement during the lesson. This allows the learners to have educational opportunities to gain the necessary 21 st century skills to be successful in today's society. Also, he affirmed that teachers are equipped with the knowledge and skills of developing of their own technology presentation when they are given 
opportunities to enhance their abilities in the areas of technology to be proficient and to be comfortable of using the ICT tools in the classroom.

\section{CONCLUSION AND SUGGESTION}

Frequent utilization of Information Communication Technology (ICT) approaches in performing pedagogy-related tasks can help teachers to develop their multimedia authoring skills which are essential in responding to the needs of the contemporary pupils who are technology-oriented visual learners. This notion that the utilization of ICT approaches significantly contributes to the development of teachers' skills in designing and developing multimedia has been affirmed by the significant relationship identified between the mentioned variables in this study. Hence, it becomes imperative for teachers to hone their multimedia authoring skills through creating an ICT-driven instruction to promote effective learning among their pupils.

To concretize this noble goal of crafting learning experiences enriched with technology integration for effective teaching, the Schools City Division may establish archive of numerous electronic instructional resources designed and created by teachers as part of their learning management system to provide avenue of sharing best practices on ICT integration among teachers within the division that can strengthen other teachers' utilization of ICT approaches in the pedagogy. With the leadership of education program supervisor in technology integration, elementary school principals within the division may collaborate with their respective master teachers in devising in-serving trainings as Learning Action Cell (LAC) sessions to help teachers develop multimedia authoring skills that can be beneficial to their delivery of instruction. An ICT skills enhancement program can also be developed by the administration of their respective schools to maximize the respondents' utilization of ICT approaches and strengthen their multimedia authoring skills. Future researchers may also conduct similar studies to further identify other factors that may influence teachers' utilization of ICT approaches and enhancement of their multimedia authoring skills.

\section{REFERENCES}

Alazam, A., Bakar, A.R., Hamzah, R., Asmiran, S. (2012). Teachers' ICT skills and ICT integration in the classroom: The case of vocational and technical teachers in Malaysia. Creative Education, 3: 70-76. DOI:10.4236/ce.2012.38b016

Aslan, A., \& Zhu, C. (2018). Starting teachers' integration of ICT into their teaching practices in the lower secondary schools in Turkey. Kuram Ve Uygulamada Eğitim Bilimleri Educational Sciences: Theory \& Practice, 18(1): 23-45. DOI 10.12738/estp.2018.1.0431

Bañez, R.M. (2016). Recency or relevance: A quest for pedagogical framework in teaching Philippine and World Literature in senior high school. Asia Pacific Journal of Multidisciplinary Research, 4(4):78-86.

Bañez, R.M., \& Callo, E.C. (2019). Awareness on regional amalgamation of teaching personnel in higher education: Views and implications. International Journal of Recent Innovations in Academic Research, 3(4):107-123.

Bautista, T.E., \& Bautista, A.F. (2015). The effect of multi-media assisted instruction on pupil's academic achievement. The Modern Teacher, 50(1):50.

Baytak, A., \& Land, S.M. (2011). An investigation of the artifacts and process of constructing computers games about environmental science in a fifth grade classroom. Educational Technology Research and Development, 59(6):765.

Boholano, H.B. (2017). Smart social networking: 21st century teaching and learning skills. Research in Pedagogy, 7(1): 21-29. DOI: 10.17810/2015.45

Bulterman, D.C.A., \& Hardman, L. (1995). Multimedia authoring tools: State of the art and research challenges. 1000. 10.1007/BFb0015268.

Caluza, L.J.B., Verecio, R.L., Funcion, D.G.D., Quisumbing, L.A., Gotardo, M.A., Laurente, M.L.P., Cinco, J.C., \& Marmita, V. (2017). An assessment of ICT competencies of public school teachers: Basis for community extension program. IOSR Journal of Humanities and Social 
Science (IOSR-JHSS), 22(3): 1-13. DOI: $10.9790 / 0837-2203040113$

Dağ, F., Durdu, L., \& Gerdan, S. (2013). Evaluation of educational authoring tools for teachers stressing of perceived usability features. Procedia - Social and Behavioral Science, 116: 888-901.

Department of Education and Training. (2005). Evaluation of the Information and Communication Technology (ICT) knowledge and skills levels of Western Australian government school teachers. Western Australia: Department of Education and Training.

Erişti, S.D., Kurt, A.A., \& Dindar, M. (2012). Teachers' views about effective use of technology in classrooms. Turkish Online Journal of Qualitative Inquiry, 3(2):3041.

Estes, J.S. (2013). Teacher preparation programs and learner-centered, technologyintegrated instruction. Retrieved:

March 18, 2019 from https://www.igiglobal.com/chapter/teacher-preparationprograms-and learnercenteredtechnology-integrated-instruction/163488

Fakhrunnisaa, N., \& Munadi, S. (2019). Relevance of multimedia expertise competency in vocational schools toward the needs of business/industrial world. Journal of Educational Science and Technology, 5(1): 58-66. DOI: https://doi.org/10.26858/est.v5i1.6923

Fortich, M.S., Marcial, D.E., \& Rendal, J.B. (2014). ICT skills enhancement training in teacher education: The case in Central Visayas, Philippines. Information Technologies and Learning Tools, 39(10):230-240.

Ghavifekr, S., \& Rosdy, W.A.W. (2015). Teaching and learning with technology: Effectiveness of ICT integration in schools. International Journal of Research in Education and Science (IJRES), 1(2), 175-191.

Hardman, L., \& Bulterman D.C.A. (1994). Authoring interactive multimedia: Problems and prospects. CWI Quarterly, 7(1): 47-66.
Hawkins, A.B. (2010). How are elementary teachers utilizing technology to enhance their instruction of literacy in the classroom?. Education Masters.Paper 33.

Liwanag, K. (2015). Extent of information and communication technology utilization in teaching: Its influence on student's academic performance. Journal of Social Sciences \& Humanities Research, 1(2):15.

Llego, M.A. (2019). Deped guidelines for master teacher promotion. Retrieved April 26, 2019 from https://www.teacherph.com/ guidelines-master-teacher-promotion/

Mishra, P., \& Koehler, M.J. (2006). Technological pedagogical content knowledge: A framework for teacher knowledge. Teachers College Record, 108, 10171054.

Muraina, I.O., \& Adeleke, I.A. (2015). Accessibility and use of authoring tools to prepare effective audio and video course materials in secondary schools in Nigeria. British Journal of Applied Science \& Technology, 11(6): 1-6.

Namaziandost, E., \& Nasri, M. (2019). The impact of using audio-visual aids on teaching listening among Iranian pre-intermediate EFL learners. LLT Journal: A Journal on Language and Language Teaching, 22(2): 246-259.

DOI: doi.org/10.24071/llt.2019.220209

Neo, T.K., \& Neo, M. (2002). Interactive multimedia education: Using authorware as an instructional tool to enhance teaching and learning in the Malaysian classroom. Interactive Educational Multimedia, 5: 80-94.

OECD (2016). Teachers' ICT and problemsolving skills: Competencies and needs. Paris: OECD Publishing.

Pond, G. (2013). Promoting information literacy through media literacy. Unpublished master's thesis, Gonzaga University at Spokane, Washington

Poole, B.J., \& Sky-McIlvain. (2009). Chapter 8: Elearning and information literacy. In B. J. Poole, E. Sky-McIlvain, J. Evans, \& Y. 
Singer (Eds.), Education for an information age: Teaching in the computerized classroom (7th ed.), (pp. 207-234). Retrieved on 9 July 2018, from http://www.pitt.edu/ poole/InfoAge7fram e.html

Ramadan, A., Chen, X., \& Hudson, L.L. (2018). Teachers' skills and ICT integration in Technical and Vocational Education and Training TVET: A case of Khartoum State-Sudan. World Journal of Education, 8(3): 31-43. doi:10.5430/wje.v8n3p31
Roblyer, M.D., \& Doering, A. H. (2013). Integrating educational technology (6th ed.). Boston, MA: Pearson.

UNESCO Institute for Statistics (2014). Information and communication technology in Asia: A comparative analysis of ICT integration and $e$ readiness. Canada: UNESCO Institute for Statistics. DOI http://dx.doi.org/10.15220/ 978-92-9189-148-1-en 